\title{
Purine and pyrimidine metabolism
}

By N. Zöllner, Department of Medicine, University of München, West Germany

Purines and pyrimidines are essential constituents of animal and plant cells and are contained in various compounds. It is interesting to consider that some of these compounds are very stable, e.g. DNA, while others are rapidly turned over, e.g. ATP. In birds and reptiles uric acid also serves to excrete nitrogen. The aim of this paper is to give a short review of purine and pyrimidine metabolism and to describe in some detail aspects important to the field of nutrition, with emphasis placed on work done in vitro and in man.

\section{Purines}

The most important structure in purine biochemistry is the nucleotide consisting of a purine base, ribose or deoxyribose, and phosphoric acid. The most important purine bases are adenine, guanine, hypoxanthine and xanthine. The ribosides of all of them are known to occur in metabolism. Adenine and guanine themselves are usually not found in the tissues of mammals, but free hypoxanthine and xanthine are intermediates in the degradation of purines. Uric acid is a divalent acid, but the second dissociation constant is so small that at around $\mathrm{pH} 7$ only the monobasic salts are formed. These are sparingly soluble in the body fluids. Peters \& van Slyke ( 1946 ) have calculated a maximum solubility of $6.5 \mathrm{mg} / 100 \mathrm{ml}$ (as uric acid) in plasma. Gout and uric acid nephropathies are due to this low solubility. Nucleosides are pentose-glycosides containing ribose or deoxyribose. Normally the linkage is with atom 9, but nucleosides with atom 3 do occur. Nucleosides are rather soluble in water. Nucleotides are phosphate esters of the pentose in the nucleoside. In mononucleotides the esters are in position $5^{\prime}$, in polynucleotides (nucleic acids) phosphate is esterified at position $5^{\prime}$ of one and position $3^{\prime}$ of the next pentose.

The biochemistry of purines has recently been reviewed by Wyngaarden \& Kelley ( 1978$)$.

\section{Metabolism of endogenous purines}

It has long been known that purines are not essential constituents of food and that ammonia is one of the precursors in purine biosynthesis. Krebs was the first to demonstrate purine synthesis in vitro in liver slices; today the pathway of purine biosynthesis is well elucidated. Three positions of the purine structure come from glycine, all other atoms are delivered from simple donors such as $\mathrm{CO}_{2}$, formyl esters or ammonia. The common end-product of purine synthesis in all vertebrates so far studied is inosinic acid (IMP), the nucleotide of hypoxanthine. One of the key substances of purine biosynthesis therefore is phosphoribosylpyrophosphate 
(PRPP), a substance we shall soon meet in other steps of purine and pyrimidine metabolism. Inosinic acid is converted to adenylic and guanylic acid by two steps. These nucleotides in turn serve as precursors of functional purine compounds such as nucleic acids and coenzymes (Fig. I).

IMP, adenylate (AMP), xanthylate (XMP) and guanylate (GMP) are dephosphorylated to their respective nucleosides by more or less specific phosphatases. In turn the nucleosides are split by nucleoside phosphorylases to deliver the free base, except for adenosine, which is fortunate because adenine is not deaminated to hypoxanthine. The deamination of the adenine moiety occurs already by adenosine deaminase, producing inosine. A lack of this enzyme occurs in certain immuno-deficiencies (Giblett et al. 1972). Guanine is deaminated by guanase to xanthine; hypoxanthine is oxidized to xanthine by xanthine oxidase which in turn oxidizes xanthine to uric acid. In man, and several other primates, this is the end of purine degradation, while in all other ureotelic animals the degradation goes on to allantoin under the action of uricase. The loss of uricase is the enzymatic defect responsible for all types of gout, primary as well as secondary. Another metabolic defect involving xanthine oxidase causes xanthinuria, a rare disease of man.

Not all purine bases proceed to the inevitable oxidation to uric acid. There are two types of salvage pathways, one leading directly back to the mononucleotides

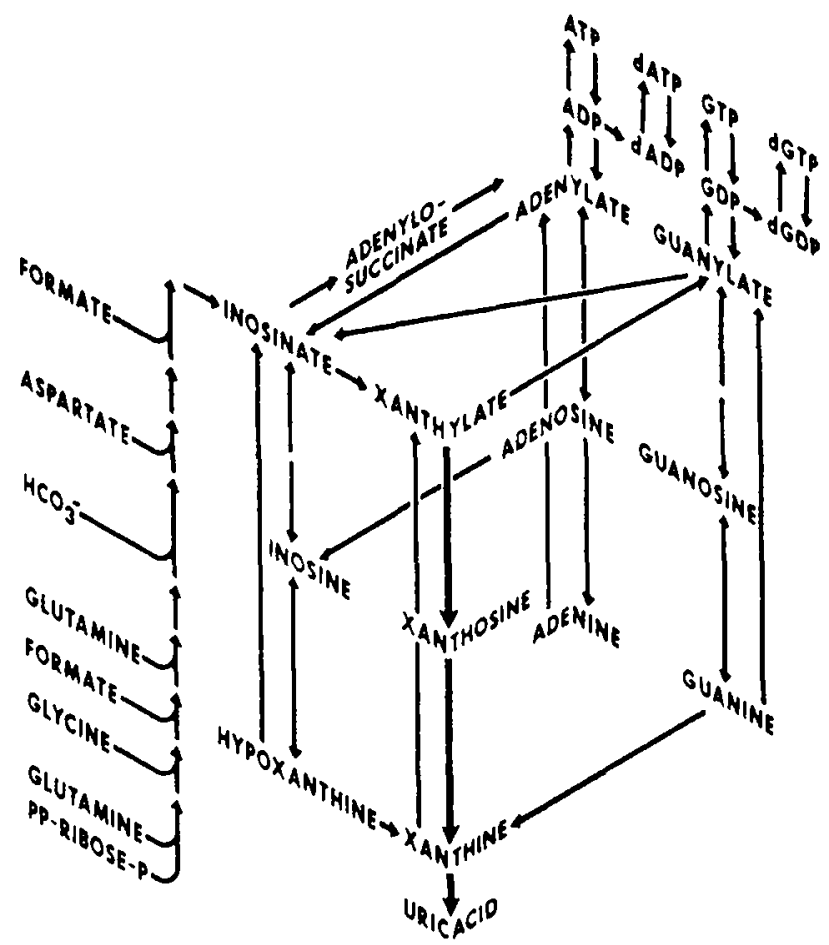

Fig. 1. Pathways of purine metabolism (Henderson et al. 1977; courtesy of the Ciba Foundation and Elsevier). 
and the second involving two steps. Of the enzymes involved, HGPRTase is the most interesting, because this phosphoribosyltransferase not only leads to a reutilization of hypoxanthine and guanine but also forms nucleotides from various drugs such as thiopurines, allopurinol and oxipurinol (Beardmore \& Kelley, I97I).

If HGPRTase is lacking in childhood, a severe disease with over-production of uric acid and neurological abnormalities (Lesch-Nyhan syndrome) results. The over-production of uric acid (two- to eightfold of the normal) clearly shows the importance of the salvage pathway (Seegmiller et al. 1967). If there is residual enzymatic activity, due to an abnormal enzyme molecule such as HGPRTase Munich (Wilson et al. 1981), juvenile-onset gout without serious neurology results (Kelley et al. 1967).

Three intimately related factors appear to play an important role in regulating or at least influencing the rate of purine synthesis, namely the intracellular concentration of PRPP, the activity of amidophosphoribosyltransferase and the intracellular concentration of IMP, AMP and GMP. Kelley et al. (1970) showed that changes in intracellular PRPP concentration led to changes in purine synthesis. This is due to the fact that the Michaelis constant of the amidotransferase is 10-100 fold higher than the physiological concentration of PRPP. Also, in HGPRTase deficiency with increased purine synthesis, intracellular concentrations of PRPP are 2-20 times higher than in controls. Holmes et al. (1973) found that the amidotransferase exists in two forms with molecular weights of 133000 and 270000 . Only the small form is said to be enzymatically active. In the presence of IMP, AMP or GMP the inactive dimer is formed, a process which is reversed by PRPP. Thus the products of purine biosynthesis may exert a feedback inhibition of its early steps while the increase of a key substrate activates the inactive form. However, the experiments just described were done with inhibitor concentrations above the probable intracellular concentrations.

If purine-free proteins are added to the diet, there is a net increase in the renal excretion of purines (Table $\mathrm{I}$ ). Reports in the literature differ somewhat as to the extent, but certainly the effects are small, possibly $1 \%$ or less of the nitrogen administered. Because of the uricosuric action of amino acids (Bowering et al. 1969), the increase in urinary uric acid cannot be safely ascribed to a small increase in synthesis (Löffler et al. $198 \mathrm{r}$ ). The question needs further investigation by

Table I. Changes in serum and urinary uric acid in healthy subjects induced by increasing amounts of dietary protein (Löffler et al. 1980). The diet was a purinefree, isoenergetic liquid formula diet; protein was increased at the cost of fat and carbohydrate in isoenergetic amounts

Serum uric acid $(\mathrm{mg} / \mathrm{r} 00 \mathrm{ml})$ Urinary uric acid $(\mathrm{mg} / \mathrm{d})$

\begin{tabular}{|c|c|c|c|c|c|}
\hline \multicolumn{6}{|c|}{ Energy $\%$ of protein } \\
\hline \multicolumn{2}{|c|}{12} & \multicolumn{2}{|c|}{24} & \multicolumn{2}{|c|}{36} \\
\hline Mean & $\mathrm{SF}$ & Mean & SE & Mean & SE \\
\hline $\begin{array}{r}3 \cdot 72 \\
287\end{array}$ & $\begin{array}{l}0.55 \\
4^{8}\end{array}$ & $\begin{array}{r}2 \cdot 84 \\
35^{6}\end{array}$ & $\begin{array}{l}0.60 \\
73\end{array}$ & $3^{86^{2 \cdot 5}}$ & $8_{4}^{0.44}$ \\
\hline
\end{tabular}


proper turnover methods. Older reports describing larger increases of uric acid production following increase of dietary protein are probably entirely due to protein sources containing purines.

Rapid administration of fructose $(\mathrm{I} \cdot 5 \mathrm{~g} / \mathrm{kg}$ per $\mathrm{h}$ ) produces an increase in serum uric acid levels and renal uric acid excretion. The same is true for sorbitol and xylitol at much lower rates (e.g. $0.3-0.5 \mathrm{~g} / \mathrm{kg}$ per $\mathrm{h}$ for xylitol) (Zöllner, 1978 ). The probable mechanism is consumption of ATP, leading to the production of inosinic acid on the one hand and fixation of inorganic phosphate on the other, thus removing the inhibition of adenylic acid deaminase.

Uric acid is excreted through the kidneys and through the gut. In the gut uric acid is rapidly metabolized by micro-organisms and can therefore not be quantitated by direct analysis. Indirect evidence suggests that the enteral excretion lies between 20 and $45 \%$ of the total excretion in normal subjects (Sørensen, 1960 ; Löfler et al. 1981).

Major places of secretion into the gastrointestinal tract are the salivary glands, the stomach and the liver. Little is known about the mechanisms. In the saliva, the rate of secretion is reported to parallel plasma concentrations; in the stomach, $\mathrm{pH}$ seems to play a role. Possibly uric acid formed in the small bowel by its xanthine oxidase diffuses into the lumen.

Renal excretion results from a combination of glomerular filtration, tubular reabsorption and tubular secretion. Probably all uric acid filtered is reabsorbed, and renal excretion is a function of secretion which in turn depends on plasma concentration. Several substances (mainly drugs and possibly amino acids) can compete with uric acid for the transport across the tubular cell. However, nutritionally more important is the profound influence of changes in the $\mathrm{NAD} / \mathrm{NADH}$ ratio and the presence of vitamin $\mathrm{K}$ antagonists such as dicoumarol (Zöllner \& Gröbner, r 969). Ketoacids, whether due to fasting or bad control of diabetes, inhibit uric acid excretion as does the ingestion of large amounts of ethanol, producing lactacidosis (Yü et al. I 957; Lieber et al. 1962).

Because they are of some use in nutritional studies, two types of drugs merit a short mention. Allopurinol is an isomer of hypoxanthine, in which $\mathrm{C}$ and $\mathrm{N}$ in positions 7 and 8 are exchanged. It is oxidized to the corresponding isomer of xanthine, called oxipurinol. Both substances inhibit xanthine oxidase, thus decreasing the formation of uric acid, lowering uric acid concentration in the plasma and excretion into the gut and in the urine and elevating the excretion of hypoxanthine and xanthine in the urine. Also, both purine isomers can be converted to various nucleotides which influence pyrimidine metabolism (Elion, 1978). It is interesting to note that many derivatives of dicoumarol and phenylindandione are uricosuric (Diamond, 1978 ).

\section{Metabolism of exogenous purines}

Although man and animals can exist on a purine-free diet, none of them does. This, of course, is due to the ubiquitous nature of purines. Presently, we eat as many purines as we synthesize. Therefore the question of whether exogenous 
purines have the same fate as those from the cells of the body (endogenous purines) is important.

If labelled adenine is injected into rats or mice it is incorporated into nucleic acids, but the label is recovered not only from adenine but also from guanine bases. The same is true if aminoimidazolcarboxamide is used. On the other hand, injected guanine is not well utilized, probably because of the active guanase already mentioned. Bone marrow of the rabbit utilizes both adenine and guanine. If labelled inosine, adenosine, IMP or AMP are administered, the labelling of purines is much weaker. Oral purines in the form of RNA or nucleosides are reported not to be incorporated at all. If free pyrimidine bases are given orally, they are not incorporated into pyrimidine compounds, except for small amounts found in the liver; however, orotic acid is incorporated. If pyrimidines are given orally as RNA, they are just as well incorporated.

Since the body does incorporate adenine, adenosine and AMP when given parenterally, but not if given orally, we must conclude that adenine-containing compounds administered orally do not reach the peripheral cells. Since the purine moiety of adenine passes through the body and exerts no metabolic effects, we must conclude that dietary adenine is converted to hypoxanthine, xanthine or uric acid before it has passed the barriers of the gut and eventually of the liver.

For the administration of exogenous purines to man the oral route is preferred, except for some special purposes such as turnover studies. Earlier, purines were given in experimental diets composed of foodstuffs. For reasons which will presently become evident this should no longer be done. Nugent \& Tyler (1959) introduced RNA as a convenient and reproducible source of purines. A few years later our group began to use isoenergetic formula diets free of purines to establish precise base-lines. Except for purines they should simulate the subjects' conventional diets and of course they must provide the necessary amounts of essential nutrients. If subjects are put on such a diet, uric acid concentrations in the plasma start to fall and renal uric acid excretion diminishes (Fig. 2). New equilibrium levels are reached after 7-10 d. We may safely assume that the new values are indicative of the turnover of endogenous purines, since uric acid is their only end-product. Using stable isotopes, we have studied the turnover of uric acid in five subjects under these conditions and found pool sizes to range from 3.39 to $4.79 \mathrm{mmol}(570$ to $810 \mathrm{mg}$ ) and fractional turnover rates of these pools to range from 0.52 to 0.82 pools/d (Table 2). The highest purine losses amounted to $467 \mathrm{mg} / \mathrm{d}$ (Löffler et al. 1982 ). Since the body turns over about $50 \mathrm{~kg} \mathrm{ATP} / \mathrm{d}$, the excretion of purines is small.

When supplements of RNA are added to the formula diets, increases in plasma uric acid concentration and urinary uric acid excretion are proportional to the load (Figs. 3 and 4) (Zöllner et al. 1972). We may safely conclude that dietary purines in the form of RNA enter the body, cross it and are converted to uric acid which is excreted by the kidney. Also the increase in plasma urate levels and in the excretion of uric acid can be used as a measure for the amounts of RNA purines administered. 

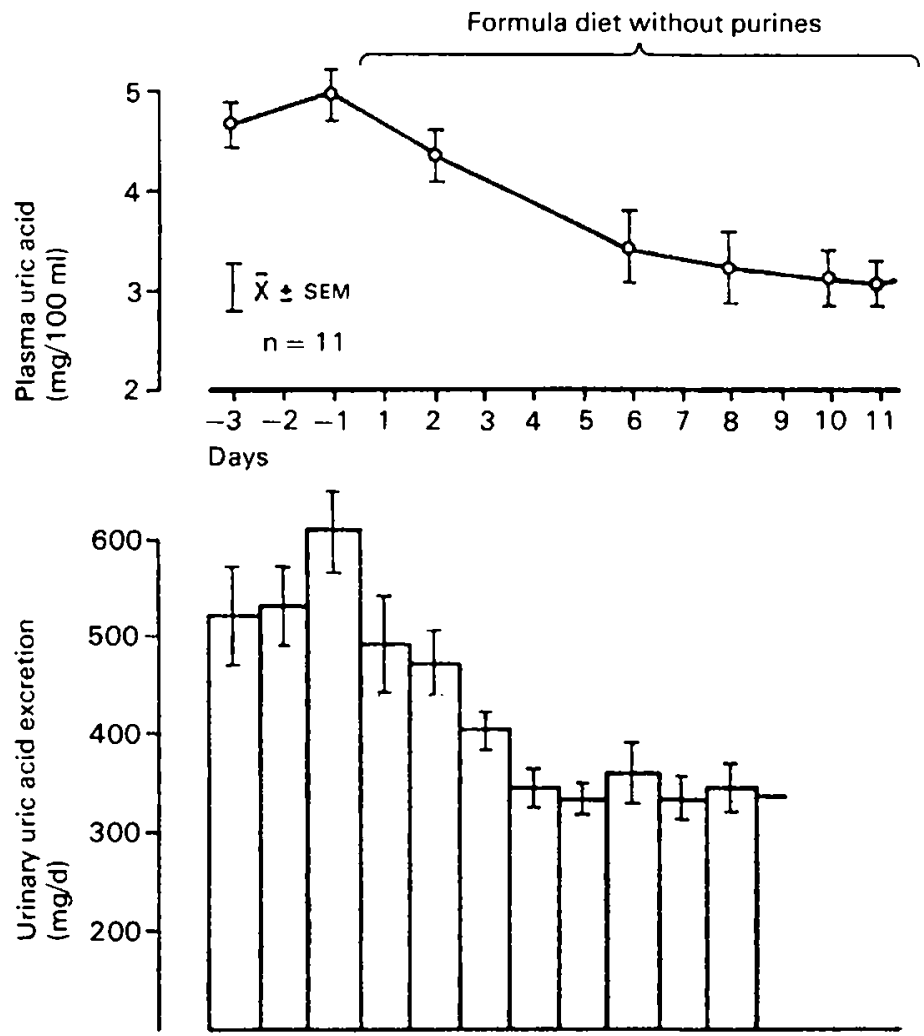

Fig. 2. Fall of plasma uric acid and urinary uric acid excretion when subjects are switched from a standard to a purine-free isoenergetic formula diet.

Table 2. Pool size and turnover of uric acid during control conditions (purinefree formula diet, $I)$ and during additional oral administration of purine nucleotides (I $g / d$ of each AMP and GMP, II). After Löffler et al. (1982)

\begin{tabular}{|c|c|c|c|c|c|}
\hline \multirow[t]{2}{*}{ Sex } & \multicolumn{2}{|c|}{$\begin{array}{c}\text { Pool size } \\
(\mathrm{mmol})\end{array}$} & \multicolumn{2}{|c|}{$\begin{array}{l}\text { Fractional turnover of } \\
\text { uric acid pool } \\
(\mathrm{l} / \mathrm{d})\end{array}$} & \multirow[t]{2}{*}{$\begin{array}{l}\text { Increase of turnover } \\
(\mathrm{mmol} / \mathrm{d})\end{array}$} \\
\hline & 1 & II & I & II & \\
\hline $\begin{array}{l}\mathbf{F} \\
\mathbf{F}\end{array}$ & $\begin{array}{l}3 \cdot 39 \\
4 \cdot 79\end{array}$ & $\begin{array}{l}4 \cdot 38 \\
8 \cdot 79\end{array}$ & $\begin{array}{l}0.82 \\
0.52\end{array}$ & $\begin{array}{l}I \cdot 21 \\
0.80\end{array}$ & $\begin{array}{l}2 \cdot 5^{2} \\
4.55\end{array}$ \\
\hline $\begin{array}{l}\mathrm{M} \\
\mathrm{M} \\
\mathrm{M}\end{array}$ & $\begin{array}{l}3 \cdot 35 \\
3.86 \\
4 \cdot 33\end{array}$ & $\begin{array}{r}7 \cdot 89 \\
9 \cdot 48 \\
12 \cdot 60\end{array}$ & $\begin{array}{l}0.63 \\
0.66 \\
0.63\end{array}$ & $\begin{array}{l}0.85 \\
0.81 \\
0.88\end{array}$ & $\begin{array}{l}4 \cdot 5^{8} \\
4 \cdot 00 \\
7 \cdot 35\end{array}$ \\
\hline
\end{tabular}

Three further conclusions can also be drawn. Firstly, the uric acid excreted via the kidneys amounts to only about $50 \%$ of the purines contained in the RNA supplement. Secondly, the slope of the line relating the amount of the supplements to the uric acid values is amazingly constant in most subjects. Thirdly, values of plasma uric acid concentration and urinary uric acid excretion obtained under the 


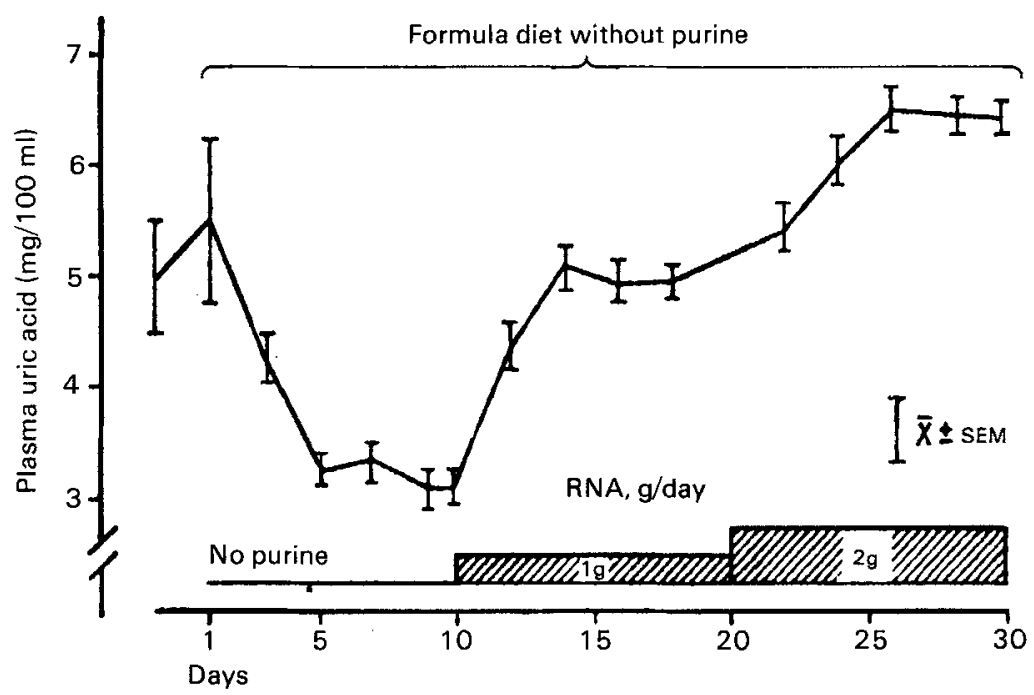

Fig. 3. Rise of plasma uric acid level upon RNA supplementation.
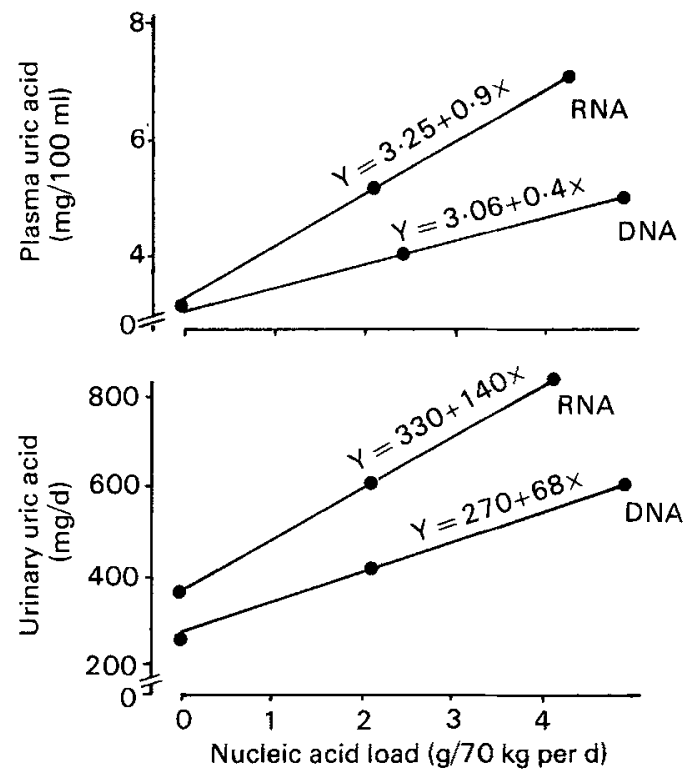

Fig. 4. Response of plasma uric acid level and urinary uric acid excretion to loads of RNA and DNA added to a purine-free liquid formula diet. In the experiments with RNA the basal uric acid excretion on the purine-free formula diet was larger than is generally our experience.

same RNA supplementation are correlated indicating that urinary excretion is a function of plasma level (Fig. 5) (Zöllner et al. 1972; Zöllner \& Griebsch, 1974).

The experiments done with RNA can be repeated with DNA, AMP or GMP. The effect of DNA supplementation on uric acid plasma concentration and renal uric acid excretion is much smaller than that of RNA (Fig. 4), whilst the effects of 


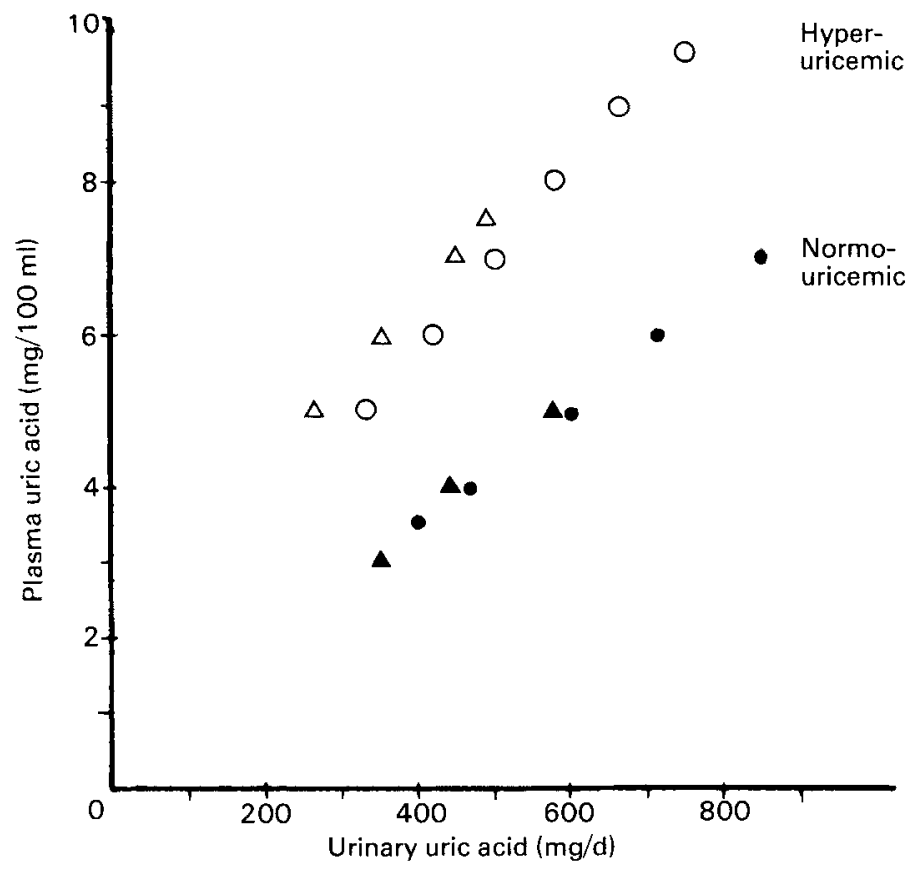

Fig. 5. Correlation of plasma uric acid levels and urinary uric acid excretion during administration of RNA $(O, O)$ and DNA $(\Delta, \Delta)$ in persons who were normouricemic (filled symbols) or hyperuricemic (plasma uric acid above $6.5 \mathrm{mg} / \mathrm{I} 00 \mathrm{ml}$ ) (open symbols) on conventional diets.

the nucleotides are larger. DNA is only partly degraded in the gut and, therefore, some of its purines escapes absorption. On the other hand, $80 \%$ of the purines of AMP or GMP are recovered as uric acid in the urine. Assuming that the remaining $20 \%$ are not digested in the gut, then about $60 \%$ of the purines from RNA and $30 \%$ from DNA are absorbed (Zöllner et al. 1972). Thus, purine sources differ in their absorption rates, a fact not taken into account in our food tables.

A further conclusion is that, since plasma uric acid concentration and urinary uric acid excretion are again correlated, the dietary source of purine has no effect on the mechanism of excretion of uric acid.

A few further comments on food tables should be made. In the dietetics of gout, so-called low-purine foods are often not restricted. However, if these foods become the major source of energy, their purine content begins to count, and indeed some of them contain more purines per unit energy than meat. In Germany we have begun to recalculate food tables for dietitians as purines per unit energy, per unit protein and per portion.

If allopurinol is given to subjects receiving a defined diet, half of the endogenous uric acid production and nearly all of the exogenous uric acid production is eliminated by the drug. Therefore, either the type of intermediates or the site of action must play a role as to whether a purine-containing compound is metabolized to uric acid or not. Since hypoxanthine and xanthine are all converted to uric acid, and a steady delivery of these intermediates would enlarge the chances of 
inhibiting its oxidation, we must conclude that the locus of xanthine oxidase inhibition is of prime importance. Since the liver and gut are the main compartments of xanthine oxidase, purines passing the gut must be deaminated and oxidized to uric acid before they reach the systemic circulation. This agrees with the fact that oxipurines are not found quantitatively in the urine and are presumably lost into the chymus by diffusion.

In summary it can be concluded that dietary purines are absorbed to a variable extent, depending on the degree of hydrolysis to nucleosides and/or nucleotides, and that they are oxidized to uric acid in the gut and excreted as uric acid, which is bad for gout but without influence on purine metabolism. Evidence for these conclusions is the renal excretion of uric acid amounting to $80 \%$ of administered purines of AMP and GMP, the finding of a nearly equivalent increase in uric acid turnover in isotope experiments upon the administration of AMP and GMP, the finding in animals that dietary purines are not incorporated into nucleic acids of the body, while dietary pyrimidines and parenteral adenine are, and finally the fact that allopurinol acts more strongly on dietary than on endogenous purines.

\section{Pyrimidines}

Interest in the metabolism of pyrimidines was stimulated when Fox et al. (1970) as well as Kelley \& Beardmore (1970) observed oroticaciduria (with both orotic acid and orotidine in the urine) in patients on allopurinol therapy. Later, Beardmore \& Kelley (197I) showed that the mononucleotides of allopurinol and oxipurinol inhibited orotidinephosphate (OMP) decarboxylase in vitro. At the same time we observed that oral administration of RNA decreased allopurinolinduced oroticaciduria considerably, e.g. from 2 I to $7 \mathrm{mg} / \mathrm{d}$.

As in purine biochemistry, the most important structure of pyrimidinecontaining compounds is the nucleotide. The most important pyrimidines are orotic acid, uracil, cytosine and thymine. Nicotinic acid and its amide should be mentioned, although they are pyridines, because they form $\mathrm{N}$-glycosides with ribose just as pyrimidines (and purines) do.

Like purine nucleotides those of pyrimidines are part of coenzymes as well as of nucleic acids. DNA contains cytosine and thymine, RNA contains cytosine and uracil.

The biochemistry of pyrimidines has recently been reviewed by Kelley \& Smith (1978).

Metabolism of endogenous pyrimidines. Like purines, pyrimidines are not essential footstuffs but synthesized from carbamylphosphate and aspartic acid, a non-essential amino acid. The resulting ring structure, dihydroorotic acid, is dehydrogenated to orotic acid.

Only after this first pyrimidine is formed does a reaction with PRPP lead to orotidine monophosphate, which in turn is decarboxylated to uridine monophosphate (UMP), the precursor of cytidine and thymidine monophosphate (CMP and TMP). 
Free pyrimidines are formed and probably salvaged in much the same way as purines. They are probably deaminated (in the case of cytidine), hydrogenated and the ring is split in a reaction similar to its formation. Due to the fact that the carboxyl group of orotic acid has been lost, the reaction products are $\beta$-alanine or B-aminoisobutyric acid. Only a small proportion of these appears in the urine. Whether these substances can be used to estimate pyrimidine turnover remains to be studied.

In contrast to purine metabolism, no convincing evidence has been discovered so far for a mechanism of self-regulation of endogenous pyrimidine biosynthesis to orotate. On the other hand, several lines of evidence suggest that exogenous purines and pyrimidines can supress biosynthesis of pyrimidines. In man there is a disease, hereditary oroticaciduria, in which the conversion of OMP to UMP is blocked due to a deficiency in orotidine-5-phosphate decarboxylase and, possibly, also in orotate phosphoribosyltransferase. The patients excrete 600-1500 mg orotic acid/d, which probably is a rough measure of an endogenous synthesis. Patients survive because dietary pyrimidine nucleosides and nucleotides are absorbed, as seen in animals and man. The amount of uridine to be given in order to alleviate the haematologic consequences of the disease is between $I \cdot 5$ and $3.0 \mathrm{~g} / \mathrm{d}$, again in good agreement with the estimation of turnover in the healthy. At such a level of uridine substitution, urinary orotic acid excretion diminishes considerably, indicating that pyrimidine synthesis is supressed.

If allopurinol is administered, the normally low excretion of orotic acid is increased. This is due to one or several nucleotides, formed from allopurinol and its oxidation product, oxipurinol, which inhibit OMP-decarboxylase and orotate phosphoribosyltransferase activities. Thus, allopurinol-induced oroticaciduria is a phenocopy, although incomplete, of the genetic disease.

Table 3. Orotic acid excretion by healthy subjects on a formula diet free of purines and pyrimidines and treated with $400 \mathrm{mg}$ allopurinol daily (basal experiment). The effects of nucleotide supplementation are shown. The values for orotic acid excretion are averages over the total experimental periods of $10 d$ each. After Zöllner \& Gröbner (1977)

$\begin{array}{lccc}\text { Nucleotide } & \text { Dose (g/d) } & \overbrace{\begin{array}{c}\text { Basal } \\ \text { experiment }\end{array}}^{\text {Excretion of orotic acid (mg/d) }} & \begin{array}{c}\text { Nucleotide } \\ \text { supplement }\end{array} \\ \text { RNA } & 4 & 19 & 6 \\ \text { RNA hydrolysate } & 4 & 18.8 & 5.5 \\ \text { AMP } & 1 & 10.9 & 10.2 \\ \text { AMP } & 3 & 16.9 & 8.8 \\ \text { GMP } & 1 & 15.2 & 7.5 \\ \text { IMP } & 1 & 22.5 & 27.5 \\ \text { CMP } & 1 & 18.9 & 12.2 \\ \text { CMP } & 3 & 21.6 & 11.9 \\ \text { LMP } & 1 & 15.8 & 11.3 \\ \text { UMP } & 3 & 16.1 & 5.7\end{array}$


Several years ago, Zöllner \& Gröbner (197I) found that oral administration of RNA decreased allopurinol-induced oroticaciduria considerably. In these experiments, RNA and allopurinol were added to the formula diet described previously, and given to healthy volunteers. One explanation of the experimental findings and the clinical observation is an inhibition of orotic acid biosynthesis by exogenous nucleotides. However, it remained to be established which nucleotide was responsible. When an alkali hydrolysate of RNA ( $4 \mathrm{~g} / \mathrm{d}$ ) (consisting of all the mononucleotides in RNA) was administered, the diminution of the oroticaciduria was the same as that with RNA itself (Zöllner et al. I975).

In the next set of experiments we used I $\mathrm{g} / \mathrm{d}$ of each of the nucleotides (Table 3 ). As none of these was as potent at reducing the oroticaciduria as $4 \mathrm{~g} / \mathrm{d}$ of the hydrolysate, we concluded that more than one nucleotide was responsible for the effect. When the effects of individual nucleotides were compared, not only were the pyrimidine nucleotides found to be effective but also guanosine monophosphate. Obviously, the influence of RNA on allopurinol-induced oroticaciduria is due to the combined effects of several of its constituents (Rauch-Janßen et al. 1976; Gröbner \& Zöllner, I977).

In order to estimate equivalent doses, we gave larger amounts of mononucleotides. As far as these experiments are completed, they demonstrate that $3 \mathrm{~g} / \mathrm{d}$ of uridylic acid is equivalent to $4 \mathrm{~g} / \mathrm{d}$ of RNA (Fig. 6). Lesser effects were observed for cytidylic acid and adenylic acid. (No information for guanylic acid is available at present.) These results again show that the effect of RNA is not the effect of any single one of its nucleotides. Orotidine- 5 -phosphate decarboxylase activity in erythrocytes was also measured in experiments with RNA hydrolysate and $\mathrm{I} g$ doses of nucleotides, the enzyme activity was not changed from its allopurinol-induced level.

We have tried to reproduce some of these results in vitro, using phytohaemagglutinine-stimulated lymphocyte cultures. Results show that purines and oxipurinol decrease the incorporation of labelled orotic acid into nucleic acid but not the incorporation of uridine (Table 4) (Banholzer et al. 1980, 1981, 1982). In addition, purines diminish the incorporation of labelled bicarbonate into orotic acid (Banholzer et al. 1981, 1982). These results are compatible with the inhibition of pyrimidine biosynthesis by purines. They do not yet offer explanations for the inhibition of pyrimidine biosynthesis by dietary pyrimidine nucleosides and nucleotides.

\section{Summary}

The pathways of purine biosynthesis and degradation have been elucidated during the last 3 o years; the regulation of the mechanisms involved is not yet fully understood, particularly with respect to quantitative aspects. Research into inborn errors of purine metabolism has provided valuable insights into purine synthesis and salvage pathways.

Nutrition experiments using purine-free formula diets and supplements with defined purine sources permit precise descriptions of the influence of various 

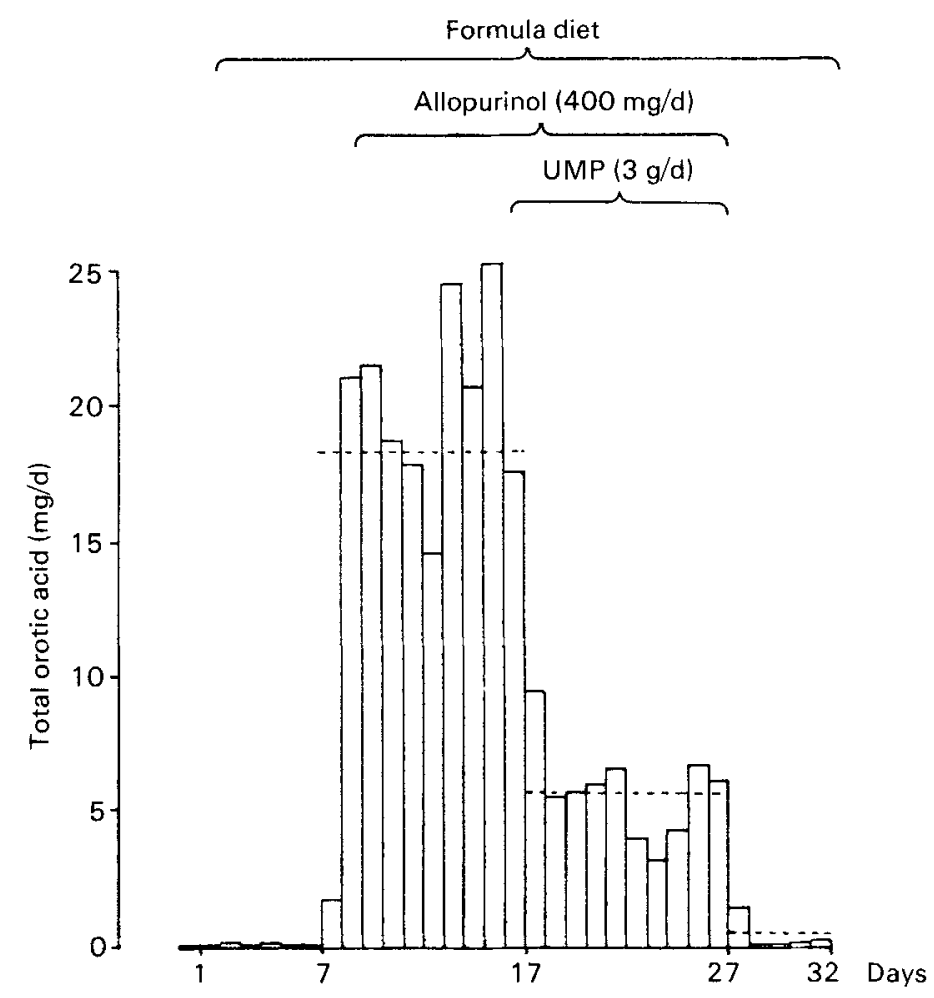

Fig. 6. Effect of UMP ( $3 \mathrm{~g} / \mathrm{d})$ on allopurinol-induced oroticaciduria (Zöllner \& Gröbner, 1977; courtesy of the Ciba Foundation and Elsevier).

Table 4. Influence of various purines on the incorporation (per cent of control) of orotic acid- $6-{ }^{14} \mathrm{C}$ or uridine-2- ${ }^{14} \mathrm{C}$ into nucleic acids of human cultured lymphoblasts

$\begin{array}{lcc}\text { Addition of } 0.5 \mathrm{mM} \text {-purines } & \begin{array}{c}\text { Incorporation of } \\ \text { orotic acid-6- }{ }^{-14} \mathrm{C}\end{array} & \begin{array}{c}\text { Incorporation of } \\ \text { uridine-2- }{ }^{14} \mathrm{C}\end{array} \\ \text { None } & 100 & 100 \\ \text { Adenine } & 35 & 98 \\ \text { Guanine } & 46 & 115 \\ \text { Hypoxanthine } & 40 & 118 \\ \text { Xanthine } & 60 & 97 \\ \text { Oxipurinol } & 35 & 104 \\ \text { Adenosine } & 68 & 70 \\ \text { Guanosine } & 52 & 99\end{array}$

dietary purines on uric acid formation. Supplements of dietary purines produce dose-proportional increases in plasma uric acid concentrations, uric acid pool size and renal uric acid excretion. The magnitude of these increases depends on the type of purine compound administered, which may limit the value of food tables for human dietetics. Purine content of food must be related not only to weight but also to energy and to protein, particularly if new foodstuffs or a vegetarian diet are ingested. 
Dietary purines appear to influence the biosynthesis of pyrimidines. In contrast to dietary purines, pyrimidines in the diet, if administered as nucleosides or nucleotides, are utilized in animals for the synthesis of nucleic acids. Much further work is necessary for a better understanding of the inter-relationships of purine and pyrimidine metabolism.

\section{REFERENCES}

Banholzer, P., Barth, Ch., Gröbner, W. \& Zöllner, N. (I982). Adv. exp. Med. Biol. (In the Press.)

Banholzer, P., Gröbner, W. \& Zöllner, N. (I980). Verh. dtsch. Ges. inn. Med. 86, 928.

Banholzer, P., Gröbner, W. \& Zöllner, N. (I98I). XXII Int. Congr. of Nutrition, San Diego.

Beardmore, Th. D. \& Kelley, W. N. (1971). F. Lab. clin. Med. 78, 696.

Bowering, J., Calloway, D. H., Margen, S. \& Kaufmann, N. A. (1969). F. Nutr. roo, 249.

Diamond, H. S. (I978). In Uric Acid. Handbook of Experimental Pharmacology, vol. 5 I [W. N. Kelley and J. M. Weiner, editors]. Berlin: Springer-Verlag.

Elion, G. B. (1966). Ann. Rheum. Dis. 25, 608.

Elion, G. B. (1978). In Uric Acid. Handbook of Experimental Pharmacology, vol. 5 I [W. N. Kelley and J. M. Weiner, editors]. Berlin: Springer-Verlag.

Fox, R. M., Royse-Smith, D. \& O'Sullivan, W. I. (1970). Science 168, 861.

Giblett, E. R., Anderson, J. E., Cohen, F., Pollara, B. \& Meuwissen, H. J. (1972). Lancet $i i$, 1067.

Gröbner, W. \& Zöllner, N. (1977). Nutr. Metab. 21, 26.

Henderson, J. F., Lowe, J. K. \& Barankiewicz, J. (1977). Purine and Pyrimidine Metabolism, Ciba Foundation Symposium 48, p. 3. Amsterdam: Elsevier.

Holmes, E. W., McDonald, J. A., McCord, J. M., Wyngaarden, J. B. \& Kelley, W. N. (I973). F. biol. Chem. 248, I 44 .

Holmes, E. W., Wyngaarden, J. B. \& Kelley, W. N. (1973). f. biol. Chem. 248, 6035.

Kelley, W. N. \& Beardmore, Th. D. (1970). Science 169, 388.

Kelley, W. N., Greene, M. L., Fox, J. H., Rosenbloom, F. M., Levy, R. I. \& Seegmiller, J. E. (1970). Metabolism 19, 1025.

Kelley, W. N., Rosenbloom, F. M. \& Seegmiller, J. E. (1967). J. clin. Invest. 46, 1518.

Kelley, W. N. \& Smith, L. H. Jr (I978). In The Metabolic Basis of Inherited Disease, p. I045 [J. B. Stanbury, J. B. Wyngaarden and D. S. Fredrickson, editors]. New York: McGraw-Hill.

Lieber, C. S., Jones, D. P., Lasowsky, M. S. \& Davidson, C. S. (1962). F. clin. Invest. 41,1863 .

Löffler, W., Gröbner, W. \& Zöllner, N. (1980). Adv. exp. Med. Biol. I22A, 209.

Löffler, W., Gröbner, W. \& Zöllner, N. (1981). Fortschr. Urol. Nephrol. 16, 8.

Löffler, W., Medina, R. \& Zöllner, N. (1982). Fresenius Z. Anal. Chem. 31 1, 437.

Nugent, C. A. \& Tyler, F. H. (1959). F. clin. Invest. 38, 1890.

Peters, J. P. \& van Slyke, D. D. (1946). Quantitative Clinical Chemistry, vol. I. Baltimore: Williams and Wilkins.

Rauch-Janßen, A., Gröbner, W. \& Zöllner, N. (1976). Verh. dtsch. Ges. inn. Med. 82, 902.

Seegmiller, J. E., Rosenbloom, F. M. \& Kelley, W. N. (1967). Science 155, 1682.

Sørensen, L. B. (1960). Scand. F. clin. Lab. Invest. 12, Suppl. 54.

Wilson, J. M., Baugher, B. W., Landa, L. \& Kelley, W. N. (I98I). 7. biol. Chem. 256, 10306.

Wyngaarden, J. B. \& Kelley, W. N. (1978). In The Metabolic Basis of Inherited Disease, p. 916 [J. B. Stanbury, J. B. Wyngaarden and D. S. Fredrickson, editors]. New York: McGraw-Hill.

Yü, T. F., Sirota, J. H., Berger, L., Halpern, M. \& Gutman, A. B. (1957). Proc. Soc. exp. Biol. 96, 809 .

Zöllner, N. (1960). Ergebn. inn. Med. Kinderheilk. 14, 32 I.

Zöllner, N. (1978). Evaluation of Non-glucose Carbohydrates in Parenteral Nutrition, p. 61. Lancaster: MTP Press. 
Zöllner, N. \& Griebsch, A. (1974). Purine Metabolism in Man, vol. 4I B, p. 435. New York: Plenum Publishing Corp.

Zöllner, N., Griebsch, A. \& Gröbner, W. (1972). Ernährungsumschau 3, 79.

Zöllner, N. \& Gröbner, W. (1969). Dtsch. med. Wschr. 94, 2652.

Zöllner, N. \& Gröbner, W. (1970). Eur. f. clin. Pharmacol. 3, $5^{6}$.

Zöllner, N. \& Gröbner, W. (1971). Z. ges. exp. Med. 156, 317 .

Zöllner, N. \& Gröbner, W. (1977). Purine and Pyrimidine Metabolism, Ciba Foundation Symposium 48, p. I65. Amsterdam: Elsevier.

Zöllner, N., Rauch-Janßen, A. \& Gröbner, W. (1975). Verh. dtsch. Ges. inn. Med. 81, I 466. 